\title{
Bioinformatics Study Applied to the Pharmacokinetic Profile of Chitosan and its Derivatives with Biomedical Applicability
}

\author{
NATALIA GUMA ${ }^{1}$, ANDREEA NASTASE ${ }^{1}$, MARILENA MOTOC ${ }^{2}$, SPERANTA AVRAM $^{\mathbf{*}}$ \\ ${ }^{1}$ University of Bucharest Department of Anatomy, Animal Physiology and Biophysics, Faculty of Biology, 36-46 Mihail \\ Kogalniceanu Blvd., 050107, Bucharest, Romania \\ ${ }^{2}$ Victor Babes University of Medicine and Pharmacy Timisoara, 2 Eftimie Murgu Sq., 300041, Timisoara, Romania
}

\begin{abstract}
The N-acetyl group attached to monomeric glucosamine monomer units of chitin confers an extremely low solubility, which makes chitin difficult to process and therefore limiting its medical potential. In order to be used as a drug administration system in the body, it is important to know about the pharmacokinetic profiles of chitosan and its derivatives, more specifically about ADME-Tox profiles (absorption, distribution, metabolism, excretion, and toxicology). Through cheminformatics and bioinformatics tools, ADMET is identifying, a set of pharmacokinetic characteristics, such as absorption, distribution, metabolism, blood-brain barrier, nervous system barrier, and toxicological characteristics of chitosan and 5 of its derivatives. Our results have shown that one can try to integrate the drug delivery system into the body.
\end{abstract}

Keywords: chitosan, chitosan derivatives, ADME-Tox, bioinformatics, cheminformatics

\section{Introduction}

Chitosan (CS) represents a polysaccharide, usually in linear form, that is obtained by deacetylation of chitin. The critical characteristics [1] of CS have been mentioned, such as good biocompatibility, hydrophilicity, high bioavailability, reduced toxicity, and ability to form films, all these features give $\mathrm{CS}$ and its derivatives important capabilities to use in various medical applications [2].

Recently, a very interesting review regarding CS and its derivatives was published by D Zhao et al [2]. In this work, the main properties of chitosan-based nanoparticles and its derivatives in the field of drug delivery, antimicrobial applications, and tissue regeneration are very well presented [2].

Polysaccharide-based drug delivery systems have challenged medical treatments due to their efficient and appropriate delivery capability. Among the various polymers, chitosan-based drug delivery systems have been of great interest because they can target molecules with specific membrane receptors [2]. On the other hand, chitosan-based drug delivery systems can enter cells, and, they can assure a more protected and efficient delivery of targeted drugs to various tissue [2]. Chitosan-based drug delivery systems have been studied in various well-organized epithelia such as pulmonary [3], nasal [4], or intestinal [5]. Another property of chitosan and its derivatives that agrees these nanoparticles to be used as drug carriers and coating molecules is the accessibility of their functional groups that facilitate chemical changes. The biodegradability of chitosan is also added to its use as a drug delivery vehicle.

It was mentioned that the chitosan molecule is disposed to degradation by lysozyme and chitinase. Also, the presence of acidic environment encountered in the stomach during oral administration induces chitosan degradation [6]. While lysozyme is naturally produced on different mucosal surfaces, chitinase production has been reported by intestinal flora.

It was shown that chitosan is insoluble in most organic solvents, limiting its applicability for encapsulation and release of hydrophobic drugs [7]. For this reason, few chitosan derivatives have been proposed to increase the encapsulation efficiency of hydrophobic drugs [7]. These derivatives can form self-assembled aggregates in aqueous solutions and have been studied as carriers of hydrophobic

*email: speranta.avram@gmail.com 
drugs. Nanoparticles obtained by structural changes of chitosan, such as hydrophobically modified glycol chitosan (HGC), is the most studied in present, due to the suitable encapsulation and delivery of hydrophobic drugs [8].

The oral delivery of drugs represents the most convenient way of drug administration for patients. Nevertheless, several factors affected oral delivery, such: the variation of $p \mathrm{H}$ into stomach, the action of enzymes during drug absorption, which can reduce the permeability of the drug into the systemic circulation. Nanoparticle technology is an increasingly studied technique to cover the limitations of oral drug delivery [9]. It was mentioned several advantages of using nanoparticle such: large surface area, small particle size, and an editable surface. The small particle size is known to increase the rate of drug dissolution [10]. In this context, the physical features of drugs that regulate nasal absorption include molecular weight, hydrophobicity and electrical charge. Drugs that do not cross the nasal membrane undergo mucociliary clearance [11]. This limitation can be reduced by developing a suitable mucoadhesive system represented by chitosan derivatives-based nanoparticles. Chitosan derivatives being structurally biodegradable, biocompatible, and with low toxicity, adheres to mucus, and open tight junctions of the nasal membrane [12].

Here, using bioinformatics and cheminformatics tools, our critical aim was to predict the pharmacokinetic profiles of chitosan and its derivatives. Currently, information on the pharmacokinetic profile (absorption, distribution, metabolism, elimination) and toxicity of chitosan and its derivatives are poorly represented. Through the advanced pharmacokinetic prediction tools, we were able to (i) quantify the intestinal absorption and skin permeability of chitosan and its derivatives, (ii) predict their critical blood-brain barrier and central nervous system permeabilities, (iii) elucidate a specific metabolic way for chitosan and its derivatives.

An important part of our work was to quantify the toxicity of chitosan and its derivatives, these features being represented by (i) mutagenic effect (AMES), (ii) hepatotoxicity, and (iii) skin sensitization.

\section{Materials and methods}

\section{Computational strategy}

\subsection{Molecular modeling and minimum energy calculation of biopolymers}

Here, from the PubChem database [13] we selected the SMILES (Simplified Molecular Input Line Entry System) files of chitosan and its derivatives, namely - chitosan malate, N-acetylchitosan, chitosan-chloride, chitosan-silicate, heptyl-chitosan, N-(hydroxypropyl) chitosan, trimethylsilylchitosan, zinc-chitosan, and chitosan-azide.

Table 1. The name of the compound and SMILE formula

\begin{tabular}{|c|c|}
\hline Name of compound & SMILE formula \\
\hline Chitosan & $\mathrm{C}(\mathrm{C} 1 \mathrm{C}(\mathrm{C}(\mathrm{C}(\mathrm{C}(\mathrm{O} 1) \mathrm{OC} 2 \mathrm{C}(\mathrm{OC}(\mathrm{C}(\mathrm{C} 2 \mathrm{O}) \mathrm{N}) \mathrm{OC} 3 \mathrm{C}(\mathrm{OC}(\mathrm{C}(\mathrm{C} 3 \mathrm{O}) \mathrm{N}) \mathrm{O}) \mathrm{CO}) \mathrm{CO}) \mathrm{N}) \mathrm{O}) \mathrm{O}) \mathrm{O}$ \\
\hline Chitosan malate & $\mathrm{CC}(=\mathrm{O}) \mathrm{NC} 1 \mathrm{C}(\mathrm{C}(\mathrm{C}(\mathrm{OC} 1 \mathrm{O}) \mathrm{CO}) \mathrm{OC} 2 \mathrm{C}(\mathrm{C}(\mathrm{C}(\mathrm{C}(\mathrm{O} 2) \mathrm{CO}) \mathrm{OC} 3 \mathrm{C}(\mathrm{C}(\mathrm{C}(\mathrm{C}(\mathrm{O} 3) \mathrm{CO}) \mathrm{O}) \mathrm{O}) \mathrm{NC}(=\mathrm{O}) \mathrm{C}) \mathrm{O}) \mathrm{NC}(=\mathrm{O}) \mathrm{C}(\mathrm{C}(=\mathrm{O}) \mathrm{O}) \mathrm{O}) \mathrm{C}(=\mathrm{O}) \mathrm{O}$ \\
\hline N-acetylchitosan & $\mathrm{CC}(=\mathrm{O}) \mathrm{NC} 1 \mathrm{C}(\mathrm{C}(\mathrm{C}(\mathrm{OC} 1 \mathrm{OC} 2 \mathrm{C}(\mathrm{OC}(\mathrm{C}(\mathrm{C} 2 \mathrm{O}) \mathrm{N}) \mathrm{O}) \mathrm{CO}) \mathrm{CO}) \mathrm{OC} 3 \mathrm{C}(\mathrm{C}(\mathrm{C}(\mathrm{C}(\mathrm{O} 3) \mathrm{CO}) \mathrm{O}) \mathrm{O}) \mathrm{N}) \mathrm{O}$ \\
\hline Chitosan-chloride & $\mathrm{C}(\mathrm{C} 1 \mathrm{C}(\mathrm{C}(\mathrm{C}(\mathrm{C}(\mathrm{O} 1) \mathrm{O}) \mathrm{N}) \mathrm{O}) \mathrm{OC} 2 \mathrm{C}(\mathrm{C}(\mathrm{C}(\mathrm{C}(\mathrm{O} 2) \mathrm{CO}) \mathrm{OC} 3 \mathrm{C}(\mathrm{C}(\mathrm{C}(\mathrm{C}(\mathrm{O} 3)(\mathrm{CO}) \mathrm{Cl}) \mathrm{O}) \mathrm{O}) \mathrm{N}) \mathrm{O}) \mathrm{N}) \mathrm{O}$ \\
\hline Chitosan-silicate & $\mathrm{C}(\mathrm{C} 1 \mathrm{C}(\mathrm{C}(\mathrm{C}(\mathrm{C}(\mathrm{O} 1) \mathrm{O}) \mathrm{N}) \mathrm{O}) \mathrm{OC} 2 \mathrm{C}(\mathrm{C}(\mathrm{C}(\mathrm{C}(\mathrm{O} 2) \mathrm{CO}) \mathrm{OC} 3 \mathrm{C}(\mathrm{C}(\mathrm{C} 4(\mathrm{C}(\mathrm{O} 3)(\mathrm{O}[\mathrm{Si}](=\mathrm{O}) \mathrm{O} 4) \mathrm{CO}) \mathrm{O}) \mathrm{O}) \mathrm{N}) \mathrm{O}) \mathrm{N}) \mathrm{O}$ \\
\hline Heptyl-chitosan & $\mathrm{O}(\mathrm{C} 1 \mathrm{C}(\mathrm{O}) \mathrm{C}(\mathrm{N}) \mathrm{C}(\mathrm{OC} 2 \mathrm{C}(\mathrm{O}) \mathrm{C}(\mathrm{N}) \mathrm{C}(\mathrm{O}) \mathrm{OC} 2 \mathrm{CO}) \mathrm{OC} 1 \mathrm{CO}) \mathrm{C} 1 \mathrm{C}(\mathrm{N}) \mathrm{C}(\mathrm{O}) \mathrm{C}(\mathrm{O}) \mathrm{C}(\mathrm{CO})(\mathrm{CCCCCC}) \mathrm{O} 1$ \\
\hline N-(hydroxypropyl) chitosan & $\mathrm{CCC}(\mathrm{NC} 1 \mathrm{C}(\mathrm{C}(\mathrm{C}(\mathrm{OC} 1 \mathrm{OC} 2 \mathrm{C}(\mathrm{OC}(\mathrm{C}(\mathrm{C} 2 \mathrm{O}) \mathrm{N}) \mathrm{O}) \mathrm{CO}) \mathrm{CO}) \mathrm{OC} 3 \mathrm{C}(\mathrm{C}(\mathrm{C}(\mathrm{C}(\mathrm{O} 3) \mathrm{CO}) \mathrm{O}) \mathrm{O}) \mathrm{N}) \mathrm{O}$ \\
\hline Trimethylsilyl-chitosan & $\mathrm{C}[\mathrm{Si}](\mathrm{C})(\mathrm{C}) \mathrm{C} 1(\mathrm{C}(\mathrm{C}(\mathrm{C}(\mathrm{C}(\mathrm{O} 1) \mathrm{OC} 2 \mathrm{C}(\mathrm{OC}(\mathrm{C}(\mathrm{C} 2 \mathrm{O}) \mathrm{N}) \mathrm{OC} 3 \mathrm{C}(\mathrm{OC}(\mathrm{C}(\mathrm{C} 3 \mathrm{O}) \mathrm{N}) \mathrm{O}) \mathrm{CO}) \mathrm{CO}) \mathrm{N}) \mathrm{O}) \mathrm{O}) \mathrm{CO}$ \\
\hline Zinc-chitosan & $\mathrm{C}([\mathrm{CH}-\mathrm{C}(\mathrm{C}(\mathrm{C}(\mathrm{CH}] \mathrm{OC} 1 \mathrm{C}(\mathrm{OC}(\mathrm{C}(\mathrm{C} 1 \mathrm{O}) \mathrm{N}) \mathrm{OC} 2 \mathrm{C}(\mathrm{OC}(\mathrm{C}(\mathrm{C} 2 \mathrm{O}) \mathrm{N}) \mathrm{O}) \mathrm{CO}) \mathrm{CO}) \mathrm{N}) \mathrm{O}) \mathrm{O}) \mathrm{O} .[\mathrm{Zn}+2]$ \\
\hline Chitosan-azide & $\mathrm{C}(\mathrm{C} 1 \mathrm{C}(\mathrm{C}(\mathrm{C}(\mathrm{C}(\mathrm{O} 1) \mathrm{O}) \mathrm{N}) \mathrm{O}) \mathrm{OC} 2 \mathrm{C}(\mathrm{C}(\mathrm{C}(\mathrm{C}(\mathrm{O} 2) \mathrm{CO}) \mathrm{OC} 3 \mathrm{C}(\mathrm{C}(\mathrm{C}(\mathrm{C}(\mathrm{O} 3)(\mathrm{CO}) \mathrm{N}=[\mathrm{N}+]=[\mathrm{N}-]) \mathrm{O}) \mathrm{O}) \mathrm{N}) \mathrm{O}) \mathrm{N}) \mathrm{O}$ \\
\hline
\end{tabular}

The compounds in the SMILES form were loaded into DiscoveryStudio/Build module [14]. The calculation of the minimum potential energy was performed by choosing the MMFF94 force field, gradient 0.5 . After minimization, the G4 electrical charges were charged. The database was formed. 


\subsection{Predicted ADME-Tox pharmacokinetic profiles}

The 3D structures of chitosan and its derivatives were loaded into DiscoveryStudio/ADME-Tox and in pkCSM database [15]. The ADME Tox (Absorption Distribution Metabolism Excretion Toxicity) study was executed on the pkCSM platform, by downloading the SMILES files of chitosan and its derivatives. We have chosen pkCSM platform based on high statistical values of predictions for selected functions: intestinal absorption $(\mathrm{R} 2=0.902)$, Steady-state Volume of Distribution (VDss) (R2 $=0.702)$, fraction unbound $(\mathrm{R} 2=0.862)$, Blood-Brain-Barrier $(\mathrm{BBB})$ permeability $(\mathrm{R} 2=0.862)$, total clearance $(\mathrm{R} 2=0.755)$ and rat Lethal Dose $(\mathrm{LD}) 50(\mathrm{R} 2=0.779)[16]$.

We selected from predictive ADME-Tox modules the following parameters: (1)Absorption- (i) Intestinal absorption (human). A molecule with an absorption of less than $30 \%$ is considered to be poorly absorbed; (ii) Caco-2 Permeability (LogPapp, $\mathrm{cm} / \mathrm{s}$ ) a compound is considered to have a high Caco-2 permeability if it has a Papp $>8 \times 10-6 \mathrm{~cm} / \mathrm{s}$, (iii) skin permeability, (iv)P-glycoprotein substrate. (2) Distribution - (i) BBB permeability (Numeric (log BB)), log BBB more than 0.3 is good BBB permeability, less than -1 is low BBB permeability; (ii) CNS permeability (Numeric (log PS))$\log$ Ps more than -0.2 , penetrate CNS, less than -3 does not; (iii) Fraction unbound (human)( Numeric $(\mathrm{Fu})$ )-predictive model was used for 562 compounds in human blood (Fu). (3) Metabolizations- (i) CYP3A4 substrate (3A4 is one of the isoform of cytochrome P450 responsible for metabolism of a drug). Excretion- total clearance (renal and hepatic clearance). (4) Toxicity- (i) AMES toxicity (mutagenic potential of a drug), (ii) Max. tolerated dose (human)( Numeric (log $\mathrm{mg} / \mathrm{kg} /$ day)) $)$ MTD = 0.477 = low; more than 0.477 = high; (iii) Oral Rat Acute Toxicity (LD50) (lethal dose for 50\% of rats used in test).

\section{Results and discussions}

By in silico tools, we evaluated the predictive ADME-Tox profiles of chitosan and its derivatives.

The Absorption results showed that: (i) chitosan and its derivatives presented poor intestinal absorption, these results lead to the idea that chitosan and its derivatives are not suitable for oral administration; (ii) all chitosan derivatives presented suitable permeability at Caco- 2 cell line (is a continuous line of heterogeneous human epithelial colorectal) but a very low permeability at skin level. These results can suggest that chitosan and its derivatives are suitable drug delivery of drugs when their skin retention is requested (Table 2).

Our results are consistent with others experimental studies [17, 18], which mentioned that chitosan derivatives such chitosan glutamate [17] or xanthan-chitosan nanofibers [18], having a good permeability at Caco2 permeability, can enhance the permeability of various synthetic drugs (e.g. acyclovir) [17] or natural compounds (e.g. curcumin) [18] in the intestinal walls.

Regarding the application of chitosan and its derivatives in the administration of drugs when penetration of skin barrier is critical, our results are correlated with the experimental studies [19, 20] that mentioned the importance of chitosan and its derivatives in the delivery system of transdermal drugs.

Table 2. Predictive absorption profile of chitosan and its derivatives

\begin{tabular}{|c|c|c|c|c|}
\hline Compounds & $\begin{array}{c}\text { Intestinal } \\
\text { absorption }\end{array}$ & Caco2 permeability & Skin permeability & $\begin{array}{c}\text { P-glycoprotein } \\
\text { substrate }\end{array}$ \\
\hline Chitosan & low & -0.84 & -14.79 & yes \\
\hline Chitosan malate & low & -0.91 & -16.78 & yes \\
\hline N-acetylchitosan & low & -0.57 & -14.86 & yes \\
\hline Chitosan-chloride & low & -0.64 & -14.64 & yes \\
\hline Chitosan-silicate & low & -0.38 & -15.63 & yes \\
\hline Heptyl-chitosan & low & -0.64 & -13.09 & yes \\
\hline N-(hydroxypropyl) chitosan & low & -0.49 & -14.51 & yes \\
\hline Trimethylsilyl-chitosan & low & -0.50 & -14.05 & yes \\
\hline Zinc-chitosan & low & -0.69 & -15.13 & yes \\
\hline Chitosan-azide & low & -0.70 & -14.48 & yes \\
\hline
\end{tabular}


For Distribution parameters, especially blood-brain barrier permeability and central nervous system permeability of chitosan and its derivatives, we obtained interesting results (Table 3 ).

Our results show that chitosan and its derivatives are not able to penetrate CNS, log CNS are included in -7.028 (chitosan) and -4.616 (chitosan azide). Instead, for BBB, chitosan and its derivatives presented a moderate permeability. Log BBB varies from -1.301 (trimethylsilyl-chitosan) to -2.619 (chitosan). These results show that trimethylsilyl-chitosan, N-(hydroxypropyl) chitosan, Nacetylchitosan, and zinc-chitosan can represent an appropriate delivery system of drugs and brain.

Table 3. Predictive distribution and excretion profiles of chitosan and its derivatives

\begin{tabular}{|c|c|c|c|c|}
\hline Compounds & BBB permeability & CNS permeability & $\begin{array}{c}\text { Fraction unbound } \\
\text { (human) }\end{array}$ & Substrate OCT2 renal \\
\hline Chitosan & -2.619 & -7.028 & 0.817 & no \\
\hline Chitosan malate & -2.236 & -5.277 & 0.441 & no \\
\hline N-acetylchitosan & -1.594 & -5.219 & -0.661 & no \\
\hline Chitosan-chloride & -1.821 & -4.884 & 0.718 & no \\
\hline Chitosan-silicate & -1.643 & -4.929 & 0.643 & no \\
\hline Heptyl-chitosan & -2.782 & -6.737 & 0.757 & no \\
\hline $\begin{array}{c}\text { N-(hydroxypropyl) } \\
\text { chitosan }\end{array}$ & -1.515 & -5.253 & 0.821 & no \\
\hline $\begin{array}{c}\text { Trimethylsilyl-chitosan } \\
\text { Zinc-chitosan }\end{array}$ & -1.301 & -5.511 & 0.810 & no \\
\hline Chitosan-azide & -1.968 & -4.616 & 0.841 & 0.781 \\
\hline
\end{tabular}

Our results regarding good predicted $\mathrm{BBB}$ permeability of chitosan and its derivatives are supported by experimental studies [21, 22]. It is known that the blood-brain barrier is critical during therapies for diseases of the central nervous system. Our results following the studies that mentioned that the efficacy of brain-targeted chitosan nanoparticle uptake by human BBB brain microvessel endothelial cells $[21,22]$.

Table 4. Predictive toxicological profiles of chitosan and its derivatives

\begin{tabular}{|c|c|c|c|c|c|}
\hline Compound & $\begin{array}{l}\text { AMES } \\
\text { toxicity }\end{array}$ & $\begin{array}{l}\text { hERG I } \\
\text { Inhibitor }\end{array}$ & $\begin{array}{l}\text { hERG II } \\
\text { Inhibitor }\end{array}$ & Hepatotoxicity & Skin sensitization \\
\hline Chitosan & no & no & no & no & no \\
\hline Chitosan malate & no & no & no & no & no \\
\hline $\mathrm{N}$-acetylchitosan & no & no & yes & no & no \\
\hline Chitosan chloride & no & no & no & no & no \\
\hline Chitosan silicate & no & no & yes & no & no \\
\hline Heptyl-chitosan & no & no & no & no & no \\
\hline $\begin{array}{c}\text { N- hydroxypropyl } \\
\text { chitosan }\end{array}$ & no & no & yes & no & no \\
\hline Trimethylsilyl chitosan & no & no & yes & no & no \\
\hline Zinc chitosan & no & no & no & no & no \\
\hline Chitosan azide & yes & no & no & no & no \\
\hline
\end{tabular}

Regarding toxicological parameters, our results show that chitosan derivatives do not have AMES toxicity except chitosan azide. Some of them show cardiotoxicity risk - N-acetylchitosan, chitosan silicate, $\mathrm{N}$ - hydroxypropyl chitosan, and trimethylsilyl chitosan. Our results show that chitosan derivatives do not induce hepatotoxicity and skin toxicity.

An important step in our work was to predict the non-toxicity and non-allergic characteristics of chitosan and its derivatives in accordance with other studies. A very recent study [23], which mentioned that chitosan and its derivatives are strong agents in inhibiting biofilm formation and can 
attenuate the properties of virulence by various pathogenic bacteria, supported our calculation results on AMES toxicity of chitosan and its derivatives. Also, our results on the hepatoprotective effects of chitosan and its derivatives agreed with the experimental data [24].

\section{Conclusions}

Chitosan nanoparticles can effectively deliver drugs to specific locations by retaining the drug locally to allow an extended time for drug absorption. The compounds studied by us so far have been little characterized in the literature, but quite often used in practice. Through this paper, we have succeeded in characterizing the cheminformatics and bioinformatics of the studied compounds. Important results were obtained from nano-QSAR studies by identifying the most hydrophobic/ hydrophilic structures, those that can be used as an optimal transport medium and very important ADMET study. So far no such studies exist, and therefore the paper presents important data for the pharmaceutical industry.

Acknowledgment: This work was supported by a grant of the Romanian Ministry of Research and Innovation, CCCDIUEFISCDI, project number PN-III-P1-1.2-PCCDI2017-0728/2018, contract no 693/2018, within PNCDI III.

\section{References}

1.SHARIATINIA, Z., Pharmaceutical applications of chitosan., Adv. Colloid Interface Sci., 263, 2019, p. 131.

2.DONGYING ZHAO, SHUANG YU, BEINI SUN, SHUANG GAO, SIHAN GUO, KAI ZHAO. Biomedical Applications of Chitosan and Its Derivative Nanoparticles., Polymers (Basel), 10, 2018, p. 462.

3.AL-QADI S., GRENHA, A., CARRION-RECIO, D., SEIJO, B., REMUNAN-LOPEZ, C., Microencapsulated chitosan nanoparticles for pulmonary protein delivery: in vivo evaluation of insulinloaded formulations., J. Control. Release, 157, 2012, p. 8.

4.HUANG TW, WEI CK, SU HW, FANG KM. Chitosan promotes aquaporin formation and inhibits mucociliary differentiation of nasal epithelial cells through increased TGF- $\beta 1$ production., J. Tissue Eng. Regen. Med., 11, 2017, p. 3567.

5.KUBBINGA M, AUGUSTIJNS P, GARCÍA MA, HEINEN C, WORTELBOER HM, VERWEI M, LANGGUTH P, The effect of chitosan on the bioaccessibility and intestinal permeability of acyclovir., Eur. J. Pharm. Biopharm., 136, 2019, p. 147.

6.BRAZ, L., RODRIGUES, S., FONTE, P., GRENHA, A., SARMENTO, B., Biodegradable Polymers: Processing, Degradation, and Applications, Nova Science Publisher, New York, 2011.

7.MOTIEI M, KASHANIAN S., Novel amphiphilic chitosan nanocarriers for sustained oral delivery of hydrophobic drugs., Eur. J. Pharm. Sci. 1, 2017, p. 285.

8.MIN, K.H., PARK, K., KIM, Y.-S., BAE, S.M., LEE, S., JO, H.G., PARK, R.-W., KIM, I.-S., JEONG, S.Y., KIM, K., Hydrophobically modified glycol chitosan nanoparticles-encapsulated camptothecin enhance the drug stability and tumor targeting in cancer therapy., J. Control. Release, 127, 2008, p. 208.

9.SHUKLA, S.K., MISHRA, A.K., AROTIBA, O.A., MAMBA, B.B., Chitosan-based nanomaterials: a state-of-the-art review., Int. J. Biol. Macromol., 59, 2013, p. 46.

10.PALACIO, J., AGUDELO, N.A., LOPEZ, B.L., PEGylation of PLA nanoparticles to improve mucus-penetration and colloidal stability for oral delivery system., Curr. Opin. Chem. Eng., 11, 2016, p. 14.

11.OZSOY Y, GUNGOR S, CEVHER E., Nasal delivery of high molecular weight drugs., Molecules., 14, 2009 , p. 3754.

12.WANG W, MENG Q, LI Q, LIU J, ZHOU M, JIN Z, ZHAO K., Chitosan Derivatives and Their Application in Biomedicine., In.t J. Mol. Sci.,21, 2020, p.487. 
$13 . * * *$, https://pubchem.ncbi.nlm.nih.gov/
$14 . * * *$, https://www.3dsbiovia.com
$15 . * * *$, http://biosig.unimelb.edu.au/pkcsm/

16.PIRES, D.E.V., BLUNDELL, T.L., ASCHER, D.B., Predicting Small-Molecule Pharmacokinetic and Toxicity Properties Using Graph-Based Signatures., J. Med Chem., 58, 2015, p. 4066.

17.MERZLIKINE A, ROTTER C, RAGO B, POE J, CHRISTOFFERSEN C, THOMAS VH, TROUTMAN M, EL-KATTAN A., Effect of chitosan glutamate, carbomer 974P, and EDTA on the in vitro Caco-2 permeability and oral pharmacokinetic profile of acyclovir in rats., Drug Dev. Ind. Pharm., 35, 2009, p. 1082.

18.FARALLI A, SHEKARFOROUSH E, AJALLOUEIAN F, MENDES AC, CHRONAKIS IS., In vitro permeability enhancement of curcumin across Caco-2 cells monolayers using electrospun xanthan-chitosan nanofibers., Carbohydr. Polym., 206, 2019, p. 38.

19.PERMANA AD, MIR M, UTOMO E, DONNELLY RF., Bacterially sensitive nanoparticle-based dissolving microneedles of doxycycline for enhanced treatment of bacterial biofilm skin infection: A proof of concept study., Int. J. Pharm. X., 2, 2020, DOI: 10.1016/J.IJPX.2020.100047

20.RAN L, ZOU Y, CHENG J, LU F., Silver nanoparticles in situ synthesized by polysaccharides from Sanghuangporus sanghuang and composites with chitosan to prepare scaffolds for the regeneration of infected full-thickness skin defects., Int J Biol Macromol., 125, 2019, p. 392.

21.ROY CHOWDHURY S, MONDAL S, MUTHURAJ B, BALAJI SN, TRIVEDI V, KRISHNAN IYER P., Remarkably Efficient Blood-Brain Barrier Crossing Polyfluorene-Chitosan Nanoparticle Selectively Tweaks Amyloid Oligomer in Cerebrospinal Fluid and A $\beta 1-40 .$, ACS Omega.,3, 2018, p. 8059.

22.SAHIN A, YOYEN-ERMIS D, CABAN-TOKTAS S, HORZUM U, AKTAS Y, COUVREUR P, ESENDAGLI G, CAPAN Y., Evaluation of brain-targeted chitosan nanoparticles through bloodbrain barrier cerebral microvessel endothelial cells., J. Microencapsul. 34, 2017,p. 659.

23.KHAN F, PHAM DTN, OLOKETUYI SF, MANIVASAGAN P, OH J, KIM YM., Chitosan, and their derivatives: Antibiofilm drugs against pathogenic bacteria., Colloids Surf B Biointerfaces., 185, 2020, p. 110627.

24.PARK SY, AHN G, UM JH, HAN EJ, AHN CB, YOON NY, JE JY., Hepatoprotective effect of chitosan-caffeic acid conjugate against ethanol-treated mice., Exp Toxicol Pathol., 69, 2017, p. 618.

$\overline{\text { Manuscript received: } 28.10 .2019}$ 